\title{
Proposed method of estimating the service life of building envelopes
}

\author{
Propuesta metodológica para estimación de la vida útil de la envolvente de los edificios
}

\author{
Leticia Ortega Madrigal (Main and Contact Author) \\ Instituto Valenciano de la Edificación \\ +34963986543 y +34963986504 \\ Av. TresForques №98, C.P.46018, Valencia, \\ Valencia,Spain \\ lortega@five.es
}

\author{
Begoña Serrano Lanzarote \\ Polytechnic University of Valencia \\ School of Architecture, Department of Mechanics of \\ Continuous Media and Structural Theory \\ apserlan@mes.upv.es
}

\section{Resumen}

La estimación de la vida útil de los elementos constructivos de un edificio y de sus materiales, es fundamental para elaborar programas de mantenimiento realistas y viables económicamente. En este sentido, el presente trabajo presenta una propuesta metodológica para estimar la vida útil de fachadas y cubiertas más frecuentes en edificación. El documento referencia utilizado ha sido la norma ISO-15686, que propone un método eficiente para estimar la vida útil, basándose en los factores que afectan a la durabilidad, pero que sin embargo está planteado de forma muy generalista de difícil aplicación. Constatada la escasa información fiable sobre durabilidades de los materiales, ha sido necesario generar una base de datos de vida útil de los elementos constructivos considerados, así como de sus materiales componentes, a partir de los mecanismos de degradación que con más frecuencia pueden afectarles. Asimismo se han identificado factores que afectan a la durabilidad y se ha propuesto un procedimiento claro para su evaluación. El método planteado, más que dar una información precisa sobre la vida útil, permite comparar diferentes sistemas constructivos y facilita al técnico su diseño en fase de proyecto. La metodología puede servir de modelo para otros elementos constructivos o para otros países

Palabras clave: Lesiones constructivas; Durabilidad; Vulnerabilidad; Predicción de la vida útil; Método de los factores.

\section{INTRODUCTION}

As Moser \& Hovde have stated in "Performance based methods for service life prediction" (Moser \& Hovde, 2004), there has recently been increased interest in determining the durability and service life of the elements, components and materials used in buildings. The reason for this greater interest is due to both financial and environmental issues.

Among the former, there are a large number of existing buildings, constructed mainly during the second half of the 20th century, which, regarded as constructed assets, represent a considerable portion of a nation's capital. It should also be remembered that annual building maintenance and inspection costs are an important charge on a national economy and can have a great influence on the competitive position of an industry or company.

Within the construction industry, refurbishment and maintenance strategies must also optimize the social and

\author{
José M. Fran Bretones \\ Polytechnic University of Valencia \\ School of Architecture, Department of Architectural \\ Construction \\ jfranbr@csa.upv.es
}

\section{Abstract}

The estimation of the service life of the construction elements of a building and its materials is an essential part of drawing up a realistic and economically viable maintenance program. In this regard, this paper presents a methodology to estimate the service life of the construction systems of outer walls and roofs frequently used in modern buildings. The reference document used was the ISO-15686 standard, which proposes an efficient method of estimating service life based on durability factors. However this method was designed for general application and is difficult to apply. Due to the scarce amount of reliable information available on material durability values, it was found necessary to generate a service-life database of the construction elements considered, as well as of their component materials, based on their common degradation mechanisms. Factors that affect durability were also identified and a clear procedure for evaluation was set up. The proposed method, rather than giving accurate information on service life, allows different construction systems to be compared and is thus of assistance in the project design phase. The methodology can also be used as a model for other construction elements and is transferable to other countries.

Keywords: Construction damage; Durability; Vulnerability; Service life prediction; Factor method.

economic benefits of existing structures. In the present economic situation in which the funds available for such actions are limited, there is a growing need to plan and prioritize the necessary maintenance work.

The planning of such work is based on predicting the time when the critical elements of the buildings reach degradation levels that exceed acceptable values. To be able to make such predictions, methods must be developed of estimating the service life of building materials and components (Garrido, Branco, \& Paulo, 2012).

With regard to environmental questions, the limited supply of both materials and power should not be forgotten, as well as the environmental impact of the buildings themselves. Durability is directly related to the search for sustainable development, a topic currently very much in the public awareness and the objective of research groups all over the world. 
According to the Spanish Construction Technological Platform (2010), the European construction sector has been responsible for approximately: $40 \%$ of all materials consumed, $40 \%$ of all energy consumed, $40 \%$ of all waste dumped on tips, $35 \%$ of all greenhouse gas emissions. In view of these figures, even small reductions in material and power consumption and waste generation would provide significant savings that would have a considerable impact on society as a whole.

An important contribution to this objective could be achieved by highlighting the importance of the durability of materials and systems and of finding reliable methods of evaluating their durability in order to predict their service life. The producers of building materials and systems are increasingly aware of this problem and are looking for ways of assessing premature degeneration risks in their products.

\section{PROBLEM DESCRIPTION}

As service life cannot always be accurately predicted, the challenge is now to achieve the most reliable estimate by using currently available information. This approach gave rise to the present research work, which consists of the proposal of a method of predicting the service life of constructive systems of outside walls and roofs commonly used in buildings in Spain.

The main aspects considered in this approach are firstly to determine the cost of the life cycle of the components in a building and secondly to estimate when these components should be replaced in order to plan a good maintenance program. In this way, the necessary capital investments in the building can be programmed for its entire service life, as well as an appropriate maintenance program, a combination which would have benefits both for society as a whole and for building owners in particular (ISO, 2011).

\section{Method}

In order to develop a specific proposal with a method adapted to the case of Spain, the following stages were carried out:

- The construction systems under study were characterized by consulting organizations recognized as authorities in the field.

- A reference service life data base was created for the components used in the selected constructive elements by means of a multicriteria study.

- A study was made of the vulnerability of the constructive elements by analysing their most commonly occurring damage using the Delphi method.

- From the analysis of the damage and their causes the quantifiable factors that influenced the durability of the elements were defined.

- Finally, an agile applicable method of estimating service life was developed.

A case study was carried out to analyse the viability of the method.

\section{Background}

The importance of predicting service life in the construction sector can be seen in diverse initiatives that saw the light in recent decades. It is important to point out that it was only after 1990 that research really began to be carried out on issues of durability and service life of building components and materials.

Many of these initiatives were included in the study, "Performance based methods for service life prediction" (Moser \& Hovde, 2004) and the most important are briefly described in the paragraphs below:

- R. Legget was the first to examine service life as a specific field of research in the 1950s (Legget \& Hutcheon, 1958).

- Many of the activities carried out were started after the United Nations Conference on the Environment and Development in Río de Janeiro in 1992 (UNCED).

- R\&D activities were carried out in the CIB «International Council for Research and Innovation in Building and Construction». The work of the W080 «Prediction of service life of building materials and components" group was done in collaboration with RILEM Technical Committee «International Association for Building Materials and Structures», under the mixed commission W080/RILEM 175-SLM «Service Life Methodologies».

- RILEM «International Association for Building Materials and Structures» published a list of recommendations for estimating the service life of building components and materials (Masters \& Brandt, 1989), which were later used by the International Organization for Standardization (ISO) as the basis for drawing up their standards for estimating service life.

- In 1984 ISO published ISO 6241 «Performance standards in building - Principles for their preparation and factors to be considered", describing the factors that influence a building's service life. ISO's Subcommittee 14 «Design life», belonging to the technical committee 59 "Building Construction», was devoted exclusively to service life. The SC 14 work produced the ISO 15686 standards for planning the service life of buildings.

- In 1988 the EU adopted the Directive 89/106/CEE regarding the harmonization of the member states' legal and administrative regulations on construction products (EU, 1989). This directive defined six essential requisites to be satisfied by a building during its service life.

- In Japan research outcomes of predicting durability and service life in both the design and maintenance phases of a building were published in "Principal Guide» in 1989 and were later summed up in an English version (AIJ, 1993).

- Many countries are making efforts to establish standards that encourage studies on durability and service life to be directed towards the planning, design, construction and use of buildings. Quantitive requisites were introduced in New Zealand's Building Code in 1992. Also in 1992, the UK published standards for predicting the durability and service life of buildings, systems, products and materials (BSI, 1992).

- In 1996, during the Third International Symposium "Applications of the performance concept in building", it was agreed that there was a need to set a design service life and to start work on standardization (Frohnsdorff, 1996) and (Frohnsdorff \& Martin, 1996). Nireki (Nireki 1996) proposed a number of different approaches to solving the problems involved in studying durability and service life. In 1977 the state-of-the-art of design service life was drawn up in (Jernberg, Sjöström, \& Lacasse, 1997).

- In 1989 the European Organization of Technical Approvals (EOTA) was founded with the task of producing European 
Technical Approval Guidelines (ETAG) for the preparation and concession of European Technical Approvals (ETA). Between 1998 and 2010 EOTA published guidelines on how to assess the service life of products (EOTA, 1998-2010) based on the previously mentioned work by RILEM and ISO.

- In 2001 the EU founded the Performance Based Building (PeBBu) thematic network within the EU's fifth framework program for thematic research on Competitive and Sustainable Growth. PeBBu's aim as regards construction materials was to examine issues related to the improvement and adoption of ISO 15686.

\section{MAIN METHODS OF PREDICTING SERVICE LIFE}

The methods proposed to date for predicting service life cannot be said to be scientifically precise, mainly due to the many different factors that must be taken into consideration that require an inter-disciplinary approach. In this section the most widely accepted methods are described.

\section{Deterministic methods}

Deterministic methods are based on the study of the factors that influence the degradation of construction elements, on understanding their modes of action and on transforming their effects into degradation functions. The factors are converted into formulas that express their action through time. The best known of these approaches is the factors method included in ISO 15686 Part 1 (ISO, 2000) and which will be explained in detail below.

\section{Probabilistic methods}

The probabilistic methods see degradation as a stochastic process that defines the probability of degradation for each property during a certain period of time (Cecconi, 2002). However, applying this method requires realistic information collected during a considerable period of time. The most popular of these methods is the Markov model. ISO 15686 Part 8 (ISO, 2008) permits the use of probability distributions or functions when applying the factors method.

\section{Engineering methods}

After explaining deterministic and probabilistic methods, another method must be identified that combines these two: engineering methods. Like the factors method, these are easy to apply and they also describe degradation processes in the same way as in the probabilistic methods (Cecconi 2002). Engineering methods can be used to identify degradation processes analytically, which means they can thus be controlled by means of maintenance planning projects (Daniotti 2003). Some of the best known engineering methods include Failure Mode Effects Analysis (FMEA) and the Performance Limits Methods.

The above three approaches form the basis for the development of diversely complex service life prediction methods.

\section{SELECTION OF THE METHOD TO BE USED}

After analysing the different approaches currently in use, it was decided to use a deterministic approach in the present study in the form of the factors method, initially published in ISO 15686 Part 1 (ISO, 2000) and later transferred to Part 8. These methods can be used to obtain approximate values until the probabilistic and engineering methods reach a sufficient level of development. However, it should be borne in mind that the service life estimated by these methods is not suitable for evaluating the risk of not reaching the established target service life.

In any case, it should be emphasized that in spite of the fact that the value obtained may not be accurate, all values calculated by the same method can be compared with each other, and durability scales can be established for the elements studied (Marteinsson, 2003). In this way durability can be established as a selection criterion between two construction systems. Similarly, determining the factors that affect degradation, as well as the weighting given to them in the method, can be of help to specialists in making decisions on projects, as they supply them with information on the combinations of products or solutions that will improve the durability of the system.

The values obtained from this method can also be used in Life Cycle Analyses, a field of study in which durability values are simply indications of the environmental impact of a product or service during all stages of their lives. A semideterministic approach was ruled out, due to the lack of reliable data bases that would have allowed us to establish factors in the form of statistical functions.

\section{Factors method}

The factors method uses a deterministic approach that allows the service life of an element or system to be quantified under specific conditions, based on a reference service life that is modified by factors dependent on the specific conditions.

The method was initially promoted in Japan in the nineties (AIJ, 1993). ISO 15686 "Service life planning» describes this method initially in its Part 1, and more recently in Part 8. ISO 15686 Part 1 (ISO, 2000) describes the factors method and gives guidelines on how to calculate the reference service life and each of the factors involved.

The following factors are included: Factor A: Quality of the materials; Factor B: Standard of the design; Factor C: Installer's skill level; Factor D: Indoor environment; Factor E: Outdoor environment; Factor F: In-use conditions; Factor G: Maintenance level.

The factors method can be expressed as a formula:

VUE $=$ VUR $\times$ factor $A \times$ factor $B \times$ factor $C \times$ factor $D \times$ factor $E x$ factor $F \times$ factor $G$. [1]. (ISO, 2000)

Where: VUE; is estimated service life and VUR is reference service life.

To date, practical applications of the factors method have been rather limited and most of the cases published are described in 
theoretical studies that give examples of its use. This is due to the fact that those involved in the field (architects, builders, property owners and administrators) are not usually familiar with the method and also because of the need for useful values for the factors.

\section{PRELIMINARY STUDIES}

\section{Scope of the study}

Outer walls and roofs are the construction elements which compose a building's outer envelope. Due to their being exposed to the weather, they require a more resistant combination of properties than other elements as regards durability, insulation, waterproofing and appearance. These elements were therefore selected for a study of their durability.

Analysing the procedures used to design the different constructive elements in a building, it can be seen that structural elements are the only elements in which the Spanish regulations require durability to be considered during the design stage. Spanish Standard EHE 08 on Durability Limits deals with structural failure due to degradation processes (Spanish Ministry of Public Works, 2008).

However, the durability of the materials used in outer walls and roofs is not considered in the design stage, apart from the requirements contained in the Building Law 38/1999, which makes the builders responsible for a period of three years for material damage in a building due to any defects that affect its habitability. Studying the durability of the elements in the building envelope is therefore considered to be of special interest.

\section{Durability of building materials used in constructive elements}

As described above, the factors method allows the service life of construction systems to be predicted using the reference service life as the starting point and modifying this value according to certain factors. The reference service life of a system, composed of a number of heterogeneous components, is considered to be equal to the value of the component whose failure would imply risks to the safety of persons and whose replacement would involve the substitution of the entire constructive element.

Continuing in the same line, in order to establish the reference service life of a construction system, the reference service life of all its components must be known.

The first step in creating a technique based on the factors method must therefore be to create a data base of the reference service life of the materials used in outer walls and roofing. A multicriteria study was therefore carried out consisting of an analysis of forty-one service life data bases published in recent decades.

Multicriteria studies are a scientific method of obtaining information to aid in decision making, basically by providing a comparative judgement between data. Relations are drawn up between different indicators and each is given a degree of importance in relation to the others, which means that a set of comparative alternatives must be available.

These may be either objective or subjective. The method is included among the evaluation tools in the Europe Aid Cooperation and Development Program. An example of this type of analysis for roofing tiles is given in Table 1.

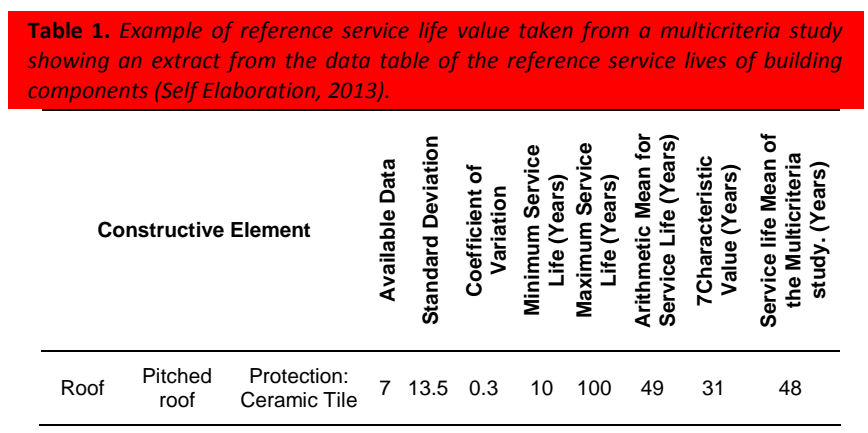

\section{Most frequent damage}

Monjo in his paper "Durabilidad vs Vulnerabilidad" (Monjo Carrió, 2007) shows that the durability of a constructive element is a function of its vulnerability, understood as a set of predictable weaknesses or pathological processes due to a component being exposed to the weather during its service life.

Using Monjo's approach as a basis, the first step in establishing the factors that influence the durability of outer walls and roofs is to determine the vulnerability of their components. For this, a study of the existing bibliography on the most commonly found degradation processes in walls and roofs was carried out. Since all of these studies were either local or were based on data from insurance companies, the former could not be considered typical of an entire country.

As the latter only included data from the claims made by their clients, neither could they be considered as representative, as not all building defects become the object of insurance claims. The first step was to resort to the Delphi method to identify the most common degradation processes in the materials under study and then identify the factors that could promote or prevent the appearance of each of these processes (Ortega, Serrano-Lanzarote, \& Fran-Bretones, 2015).

The Delphi method consists of individually consulting a panel of experts by means of successive rounds with a questionnaire, using the average results of the preceding round as support, in order to encourage convergence of opinions. The method was applied bearing in mind the frequency of the degradation processes, the concern they could cause to the owners, the level of degradation, and the investment necessary to repair the defects.

\section{Identification and proposal of the factors}

A study was made of the symptoms, possible causes, feasible preventive actions, and the factors that affect the appearance 
and/or the advance of degeneration for all the degradation processes identified by the Delphi method.

After analyzing the factors that affect the appearance of different degradation processes, certain factors were selected and organized in the same structure as used in ISO 15686-1 (ISO, 2000), but as the Code itself recommends, subdivided into smaller factors. The order of the factors was also changed and Factor E "Outdoor Environment" was put first to coincide with the stages in a building design project. The selection of the factors to be considered was carried out under the following premises:

- The conditions required by the standards are understood to be mandatory and were therefore assumed to be complied with automatically and were thus not considered.

- The method needs to be applied effectively in a simple way, so that all the necessary information must be easily available to the specialist carrying out the work.

Figure1.Types of outer walls and roofing selected for the application of the method
(Self-Elaboration, 2013 .

\section{RESULT: PROPOSED METHOD}

\section{Construction systems considered in applying the method}

After choosing the factors, a proposed method for the two most typical systems in outer walls and roofs was drawn up, as shown in Figure1.

\section{Application of proposed method}

The aim of the method is to estimate the service life of a construction system based on reference service life and correcting it according to certain factors dependent on the conditions of the system. ISO 15686 Part 1 (ISO, 2000) describes the factors method according to the formula given in [1]. Users of the method must fill in a table with the characteristics of the construction element under study, assigning specific factors to arrive at an estimate of service life, which should be greater than the design service life assigned to the element in the standards. If this is not so, steps should be taken to alter the design of the constructive system in order to lengthen its estimated service life.

\section{Reference service life}

As has already been indicated, estimated service life is based on reference service life multiplied by various factors. In the proposed method, reference service life is determined by an analysis of the components included in the constructive system, choosing as the value of the reference service life the component whose failure would involve a risk to human safety and whose replacement would involve replacement of the entire constructive system. The service life of each component was obtained from the service life data base given in Section 6.2.. Figure2 shows the analysis carried out for the four construction systems considered and the reference service life established for each one.

\section{Factors included in the method}

ISO 15686 Parte 1 (ISO 2000) describes the factors method and gives general indications on how to establish each factor. The present method proposes the use of factors given in the Factors Method section. The method proposed in this paper uses a greater number of factors than those included in the standards and assigns to each factor another set of factors that defines the concept proposed by ISO 15686-1 (ISO, 2000) for each construction element. The number of factors that define each concept varies according to the section and the construction element under study. Specific factors were selected, as has been indicated above, from an analysis of the factors that have an impact on the occurrence of the most common building defects.

\section{Values assigned to each factor}

In the proposed method, each factor gives the user different selection options. According to the option selected, the factor will have a value lower, equal or higher than one. The estimated system service life is the result of multiplying reference service life by the value assigned to each of the factors. Figure 3 shows an example. In its examples, ISO15686-1 (ISO, 2000) assigns values of $0.8,1$ and 1.2 to each factor, according to whether the factor has a positive, null or negative effect on the element's service life. Gaspar \& De Brito concluded after many studies on predicting service life that the use of default values to modify factors, such as $0.8,1$ and 1.2 , should not be considered the 
standard solution when applying the method (Gaspar \& de Brito, 2008).

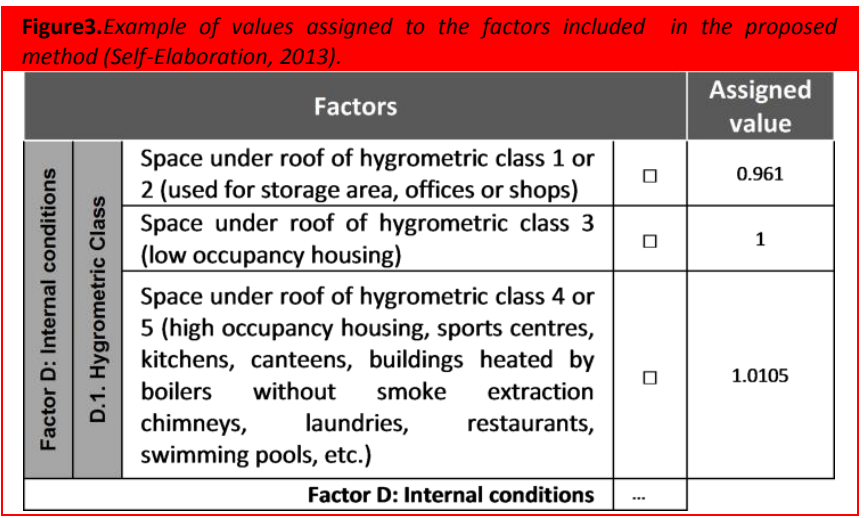

Figure 2.Reference service lives established for the construction elements
considered (Self-Elaboration, 2013).
\begin{tabular}{|l|l|}
\hline \multicolumn{1}{|c|}{ Clay brick outer wall } & $\underline{37}$ \\
\hline System components & 43 \\
LC: Clay brick masonry & $\underline{\mathbf{8 1}}$ \\
RM: Intermediate layer of mortar & $\mathbf{4 6}$ \\
AT: Non-hydrophylic insulation & $\mathbf{8 1}$ \\
LH: Hollow clay brick masonry & Estimated service life \\
RI: Internal rendering layer of plaster, mortar or tiles. & Reference service life of system \\
\hline
\end{tabular}

\begin{tabular}{|l|c|}
\hline \multicolumn{1}{|c|}{ Outer wall with rendering } & Estimated service life \\
\hline \multicolumn{1}{|c|}{ System components } & 37 \\
RE: rendering & $\underline{81}$ \\
LC: Clay brick masonry & 43 \\
AT: Non-hydrophylic insulation & $\underline{81}$ \\
LH: Hollow clay brick masonry & 46 \\
RI Internal rendering layer of plaster, mortar or tiles. & $\mathbf{8 1}$ \\
\hline \multicolumn{2}{|c|}{ Reference service life of system } \\
\hline
\end{tabular}

\begin{tabular}{|lc|}
\hline & \\
Conventional roof with heavy covering & 51 \\
\hline \multicolumn{1}{|c|}{ System components } & 37 \\
P: Flooring. & 30 \\
MA: Bonding or levelling material & 23 \\
Csa: Dividing layer under anti-puncture protection. & 30 \\
I: Waterproofing layer & 40 \\
Cs: Dividing layer & 41 \\
AT: Insulation & 39 \\
B: Vapour barrier & $\mathbf{7 8}$ \\
FP: Sloping layer of concrete with light aggregates & $\mathbf{7 8}$ \\
SR: Supporting layer & \\
\hline Reference service life of system & \\
\hline
\end{tabular}

\begin{tabular}{|lc|}
\hline & \\
\hline & \\
& \\
\hline \multicolumn{1}{|c|}{ Soof with gravel comering } & Estimated service life \\
\hline P: Gravel layer & 40 \\
Csa: Dividing layer under anti-puncture protection & 30 \\
I: Waterproofing layer & 23 \\
Cs: Dividing layer & 30 \\
AT: Insulation & 40 \\
B: Vapour barrier & 41 \\
FP: Sloping layer of concrete with light aggregates & 39 \\
SR: Supporting layer & $\mathbf{7 8}$ \\
\hline Reference service life of system & $\mathbf{7 8}$ \\
\hline
\end{tabular}

In our proposal, the standard's range was considered too wide for the number of factors taken into account in the proposal (as many as 28 factors in some constructive systems). If the range proposed in the standards had been used, with the number of factors proposed in this work, the minimum and maximum service lives thus obtained would be either unreasonably low or high. In the present case, three levels were established for each factor in accordance with the minimum and maximum service life that was required to be obtained for each construction system. In other words, the values of each factor with a negative effect on service life when multiplied together give the minimum service life of the element.

This means if an outer wall or roof has a negative value for all its factors, the minimum service life of this element would be obtained. In the same way, the values of all factors with a positive effect when multiplied together give the maximum service life. Finally, the values of factors with a null effect on service life are equal to 1 , as indicated in the standards.

\section{Operating files for the proposed method}

The operating files for the proposed method are given below, as visualized in the application tool, with which the files for the construction elements must be completed in order to obtain the service life. Once the tables included in the files have been completed, the minimum and maximum service lives that can be obtained by applying the method are shown below the box containing the element's service life. The estimated service life obtained by applying the method, after indicating the options for each factor, will be the result of multiplying the values of each factor, and is given automatically by the proposed tool. Figure 4 shows the operational file for a brick-faced outer wall.

\section{CONCLUSIONS}

At the present time, thanks to the numerous studies carried out in the field of predicting service life, the calculation methods are quite advanced, although due to the many factors involved, service life still cannot be predicted with complete accuracy. The publication of ISO 15686 was a great step forward in achieving a prediction method for construction elements and materials, but there are still important issues to be tackled in the international field, including:

- Reference data bases for the service life of component materials and construction elements.

- Degradation studies that allow degradation mechanisms and factors to be characterized.

- Guidelines for applying the service life estimation method that include detailed examples.

The main contribution of the present work, as a result of its general objective, is the method proposed to estimate the service life of the most commonly used construction systems in outer walls and roofs, based on the factors method given in ISO 15686. The present proposal provides better definition of the factors that affect the durability of walls and roofs than ISO 15686 , together with a clear method of assessing each of these factors with the data on durability obtained from the work on the construction systems studied. 
Characterizing the factors means that the values of the service lives obtained from the method can be compared to each other. An attempt was also made to respond to the needs that arose from the development of the method by generating a service life data base for the components of the construction elements studied and by examining the most common degradation mechanisms by which they are affected. This data base, in spite of being developed in the ambit of service life prediction, could also be useful in other areas, such as in establishing a replacement plan for the constructive components in a building as part of its maintenance program.

Having identified the most common degradation mechanisms in outer walls and roofs, as well as their causes and prevention, apart from the use made of these in the present study, they could also be applied in a number of different fields, e.g. in technical inspections of buildings. Our main aim was not to establish exact durability values either for components or construction systems.

Our aim has been rather to open up a line of research that, after publishing the results, would allow us to demonstrate their validity and usefulness to those involved in the sector. The data thus obtained, either in the form of a data base of the durability of building components or applying the proposed prediction method to construction systems, should be regarded as approximations that allow different construction systems to be compared as regards durability, but should never be interpreted as precise information on the service life of the component or system. In any case, if the method is applied in the project stage it will give information to the project manager on the main factors that can affect the durability of a system and will help him to take decisions as regards its improvement.

Consequently, the information provided by the method should be regarded as a qualitative rather than a quantitative estimation. At the present time, when the building sector needs to change the model it has been applying in recent decades, an advance of the type achieved in the present work in the form of a method of calculating estimated service life of outer walls and roofs, is a step forward in improving the quality and sustainability of the construction sector and provides more information on the construction systems and materials used. The functioning of construction systems cannot be improved without being familiar with their behaviour.

Regarding the development of future work related to this research, on the one hand the development of similar methods in other countries based on the present work is possible. This new research would have to take into account specific national degradation studies on building envelopes, as for example the research carried out by Carlos M. Melo and Helena Carasek regarding the relation between the deterioration of outside building walls and heavy rain (Melo Júnior \& Carasek, 2014).

On the other hand, to have a methodology available for estimating the service life of construction elements will allow progress in other fields of study, such as in Life Cycle Cost Analysis, life cycle analysis, or in estimating a replacement schedule for these items, to ensure proper planning maintenance. 


\section{REFERENCES}

AIJ, Architectural Institute of Japan (1993). The English Edition of Principal Guide for Service Life Planning of Buildings. Japan: Architectural Institute of Japan.

BS 7543 (1992). British Standards Institution. Guide to Durability of Buildings and Building Elements, Products and Components: British Standards Institution: London, United Kingdom.

New Zealand Building Code. (1992). Building Industry Authority. New Zealand Building Code. Clause B2 Durability. Building Industry Authority: Wellington, New Zealand.

Cecconi, F. (2002). Performance lead the way to service life prediction. 9th International conference on Durability of Building Materials and Components, Brisbane.

Daniotti, B. (2003). Durability evaluation and control to prevent building pathologies. 2o Simpósio Internacional sobre Patologia, Durabilidade e Rehabilitaçao dos Edificios, Lisboa.

European Organization for Technical Approval. (1998-2010). Guidelines for European Technical Approval. Belgium.

Frohnsdorff, G. (1996). Predicting the service lives of materials in construction. 4th Materials Engineering Conference on Materials for the new millennium, Washington, DC.

Frohnsdorff, G., \& Martin, J. W. (1996). Towards prediction of building service life: The standards imperative. 7th International Conference on the Durability of Building Materials and Components, Estocolm.

Garrido, M., Branco, F., \& Paulo, P. (2012). Service life prediction of façcade paint coatings in old buildings. Construction and building materials, vol 29, 394-402.

Gaspar, P., \& de Brito, J. (2008). Service life estimation of cementrendered facades. Building Research \& Information, 36(1), 44-55.

ISO 15686-8. (2008). International Organization for Standardization. Buildings and constructed assets - Service life planning: Part 8: Reference service life. International Organization for Standardization: Geneva, Switzerland.

ISO 15686-1. (2000). International Organization for Standardization. Buildings and constructed assets - Service life planning - Part 1: General principles. International Organization for Standardization: Geneva, Switzerland.

ISO 15686-1. (2011). International Organization for Standardization. Buildings and constructed assets - Service life planning - Part 1: General principles and framework. International Organization for Standardization: Geneva, Switzerland.

Jernberg, P., Sjöström, C., \& Lacasse, M. A. (1997). State of the art report. Materials and Structures, 30(1), 22-25.

Legget, R. F., \& Hutcheon, N. B. (1958). The durability of buildings. Symposium on Some Approaches to Durability in Structures. American Society for Testing Materials, 236, 35-44.

Marteinsson, B. (2003). Durability and the factor method of ISO 156861. Building research and information, 31(6), 416-426.

Masters, L. W., \& Brandt, E. (1989). Systematic methodology for service life prediction of building materials and components. Materials and Structures, 22(5), 385-392.
Melo Júnior, C. M., \& Carasek, H. (2014). Relationship between the Deterioration of Multi Story Buildings Facades and the Driving Rain. Journal of Construction, 13(1), 64-73.

EHE. (2008). Ministerio de Fomento. Instrucción hormigón estructural. Ministerio de Fomento: Madrid.

Monjo Carrió, J. (2007). Durabilidad vs Vulnerabilidad. Informes de la Construcción, 59(507), 43-58.

Moser, K., \& Hovde, P. J. (2004). Performance based methods for service life prediction. Rotterdam: CIB report 294.

Nireki, T. (1996). Service Life Design. Construction and BuildingMaterials, 10(5), 403-406.

Ortega, L., Serrano-Lanzarote, B., \& Fran-Bretones, J. M.a . (2015). Most common pathological processes identification in facades and roofs in Spain from Delphi method. Informes de la Construcción, 67 (537).

Plataforma Tecnológica Española de la Construcción. Visión estratégica 2025. (2010).Retrieved from http://blog.construmatica.com/wpcontent/uploads/2011/12/8be12bfeace05a2aa5edd81ec905765c. pdf [19.03.13]

Unión Europea. (1989). 89/106/CEE Directiva del consejo de 21 de Diciembre de 1988 relativa a la aproximación de las disposiciones legales, reglamentarias y administrativas de los Estados miembros sobre los productos de construcción. Diario Oficial de las Comunidades Europeas.

89/106/EEC(1989). Council Directive 89/106/EEC of 21 December 1988 on the approximation of laws, regulations and administrative provisions of the Member States relating to construction products, EU Legislation. 


\begin{tabular}{|c|c|c|c|c|}
\hline \multicolumn{4}{|c|}{ Clay brick masonry outer wall } & \multirow{2}{*}{\begin{tabular}{|c|}
$\begin{array}{c}\text { Reference } \\
\text { service } \\
\text { life } \\
V_{R}\end{array}$ \\
$\mathbf{8 1}$ \\
$\begin{array}{c}\text { Assigned } \\
\text { value }\end{array}$ \\
\end{tabular}} \\
\hline & \multicolumn{3}{|c|}{ Factors } & \\
\hline \multirow{12}{*}{ 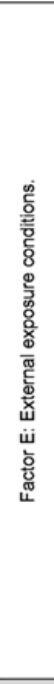 } & \multirow{3}{*}{$\begin{array}{l}\text { E.1 } \\
\text { Environmental } \\
\text { class: } \\
\text { atmospheric } \\
\text { pollution. } \\
\end{array}$} & Marine environment or industrial pollution. & ㅁ & 0.967 \\
\hline & & Inland urban environment. & 口 & 1.000 \\
\hline & & Inland rural environment without pollution. & 口 & 1.033 \\
\hline & \multirow{3}{*}{$\begin{array}{l}\text { E.2 Radiation } \\
\text { exposure. }\end{array}$} & $\begin{array}{l}\text { Facade facing to east, west or south, } \\
\text { located in climate zone IV or } V \text { (according } \\
\text { to CTE-DB-H5) without shadow cast that } \\
\text { protect it of radiation peak hours in the } \\
\text { summer months. } \\
\text { Facade facing to north or shaded all day. }\end{array}$ & 口 & 0.967 \\
\hline & & $\begin{array}{l}\text { Facade facing to east, west or south, } \\
\text { located in climate zone I, II or III (according } \\
\text { to CTE-DB-H5). }\end{array}$ & 口 & 1.000 \\
\hline & & $\begin{array}{l}\text { Facade facing to east, west or south, } \\
\text { located in climate zone IV or V (according } \\
\text { to CTE-DB-H5) with shadow cast that } \\
\text { protect it of radiation peak hours in the } \\
\text { summer months. }\end{array}$ & 口 & 1.033 \\
\hline & \multirow{3}{*}{$\begin{array}{l}\text { E.3 Rain water } \\
\text { exposure } \\
\text { frequency. }\end{array}$} & $\begin{array}{l}\text { Rainfall zone of average I or II (according to } \\
\text { CTE-HS1). }\end{array}$ & 口 & 0.967 \\
\hline & & $\begin{array}{l}\text { Rainfall zone of average III or IV (according } \\
\text { to CTE-HS1). }\end{array}$ & 口 & 1.000 \\
\hline & & $\begin{array}{l}\text { Rainfall zone of average } V \text { (according to } \\
\text { CTE-HS1). }\end{array}$ & ㅁ & 1.033 \\
\hline & \multirow{3}{*}{$\begin{array}{l}\text { E.4 Wind } \\
\text { exposure level. }\end{array}$} & $\begin{array}{l}\text { Wind exposure level V1 (according to CTE- } \\
\text { HS1). }\end{array}$ & $\square$ & 0.967 \\
\hline & & $\begin{array}{l}\text { Wind exposure level V2 (according to CTE- } \\
\text { HS1). }\end{array}$ & $\square$ & 1.000 \\
\hline & & $\begin{array}{l}\text { Wind exposure level V3 (according to CTE- } \\
\text { HS1). }\end{array}$ & $\square$ & 1.033 \\
\hline & & Factor E:External exposure conditions & & \\
\hline & \multirow{3}{*}{$\begin{array}{l}\text { A.1 Resistance to } \\
\text { freeze/thaw of } \\
\text { clay bricks. }\end{array}$} & F0: Passive exposure (CE marking). & 口 & 0.967 \\
\hline & & F1: Moderate exposure (CE marking). & 口 & 1.000 \\
\hline & & F2: Severe exposure (CE marking). & 口 & 1.033 \\
\hline & \multirow{3}{*}{$\begin{array}{l}\text { A.2 } \\
\text { Waterproofness } \\
\text { of the brick } \\
\text { masonry. }\end{array}$} & $\begin{array}{l}\text { Not used low-suction bricks, or water- } \\
\text { repellent, or vitrified. }\end{array}$ & $\square$ & 0.967 \\
\hline & & Use low-suction bricks. & $\mathrm{\square}$ & 1.000 \\
\hline & & Use water-repellent bricks, or vitrified. & 口 & 1.033 \\
\hline & \multirow{3}{*}{$\begin{array}{l}\text { A. } 3 \text { Active soluble } \\
\text { salts contained in } \\
\text { the clay bricks. }\end{array}$} & Clay brick category S0 (CE marking). & $\mathrm{Q}$ & 0.967 \\
\hline & & Clay brick category S1 (CE marking). & 口 & 1.000 \\
\hline 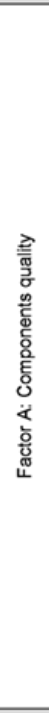 & & Clay brick category S2 (CE marking). & $\square$ & 1.033 \\
\hline$\stackrel{\infty}{E}$ & \multirow{2}{*}{$\begin{array}{l}\text { A. } 4 \text { Clay bricks } \\
\text { efflorescence. }\end{array}$} & Clay brick with little efflorescence. & 口 & 0.967 \\
\hline Фَ & & Clay brick with no efflorescence. & $\square$ & 1.000 \\
\hline$\underline{E}$ & \multirow{2}{*}{$\begin{array}{l}\text { A.5 Use of } \\
\text { industrial mortars }\end{array}$} & No & 口 & 0.967 \\
\hline 0 & & Yes & 口 & 1.000 \\
\hline 递 & \multirow{3}{*}{$\begin{array}{l}\text { A.6 Sort of } \\
\text { masonry mortar } \\
\text { (not applicable fo } \\
\text { light mortars or } \\
\text { thin joint). }\end{array}$} & Mortar class M1 or M 2.5 & $\mathrm{\square}$ & 0.967 \\
\hline 总 & & $\begin{array}{l}\text { Mortar class M5 (provided that the brick } \\
\text { compressive strength is longer than } 0.75 \\
\text { that of the mortar). }\end{array}$ & 口 & 1.000 \\
\hline & & $\begin{array}{l}\text { Mortar class M7 or more (provided that the } \\
\text { brick compressive strength is longer than } \\
0.75 \text { that of the mortar). }\end{array}$ & 口 & 1.033 \\
\hline & \multirow{3}{*}{$\begin{array}{l}\text { A.7 Corrosion } \\
\text { resistance of the } \\
\text { metal elements. }\end{array}$} & Unprotected metal elements in facade. & $\mathrm{Q}$ & 0.967 \\
\hline & & $\begin{array}{l}\text { Protected metal elements in facade } \\
\text { (galvanized steel, anodized or lacquered } \\
\text { aluminium). }\end{array}$ & 口 & 1.000 \\
\hline & & $\begin{array}{l}\text { Stainless steel in facade or no metals in } \\
\text { facade. }\end{array}$ & 口 & 1.033 \\
\hline \multirow{10}{*}{ 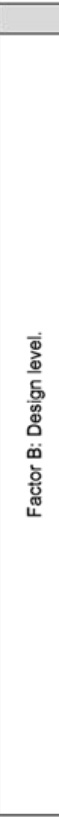 } & & Factor $\mathrm{A}$ : Components quality. & & \\
\hline & \multirow{3}{*}{$\begin{array}{l}\text { B.1 Facade } \\
\text { waterproofness } \\
\text { level. }\end{array}$} & $\begin{array}{l}\text { Waterproofness level } 1 \text { or } 2 \text { according to } \\
\text { the CTE-DB-HS } 1 \text { (provided that it keeps the } \\
\text { minimum waterproofness level required by } \\
\text { the standard) }\end{array}$ & 口 & 0.967 \\
\hline & & $\begin{array}{l}\text { Waterproofness level } 3 \text { or } 4 \text { according to } \\
\text { the CTE-DB-HS1 (provided that it keeps the } \\
\text { minimum waterproofness level required by } \\
\text { the standard) }\end{array}$ & 口 & 1.000 \\
\hline & & $\begin{array}{l}\text { Waterproofness level } 5 \text { according to the } \\
\text { CTE-DB-HS1 }\end{array}$ & 口 & 1.033 \\
\hline & \multirow{3}{*}{$\begin{array}{l}\text { B.2 Correct } \\
\text { disposal of } \\
\text { waterproof } \\
\text { sheets. }\end{array}$} & $\begin{array}{l}\text { Not waterproof sheets are available in all of } \\
\text { the following locations: the start of the } \\
\text { brickwork, the encounter of the brickwork } \\
\text { with slabs, the encounter of the brickwork } \\
\text { with the land or horizontal decks, lintels, } \\
\text { jambs and window ledges. }\end{array}$ & & 0.967 \\
\hline & & $\begin{array}{l}\text { Waterproof sheets are available in all of the } \\
\text { following locations: the start of the } \\
\text { brickwork, the encounter of the brickwork } \\
\text { with slabs, the encounter of the brickwork } \\
\text { with the land or horizontal decks, lintels, } \\
\text { jambs and window ledges. }\end{array}$ & & 1.000 \\
\hline & & $\begin{array}{l}\text { In the design is defined the appropriate } \\
\text { details to prevent the rainwater goes into } \\
\text { the building through the placement of } \\
\text { waterproof sheets in the start of the } \\
\text { brickwork, in the encounter of the brickwork } \\
\text { with slabs, in the encounter of the brickwork } \\
\text { with the land or horizontal decks, in lintels, } \\
\text { in jambs and in window ledges. }\end{array}$ & & 1.033 \\
\hline & \multirow{3}{*}{$\begin{array}{l}\text { B. } 3 \text { Distance } \\
\text { between } \\
\text { movement } \\
\text { vertical joints. }\end{array}$} & $\begin{array}{l}\text { Distance between movement vertical joints } \\
\text { more than } 15 \mathrm{~m} \text {. }\end{array}$ & 口 & 0.967 \\
\hline & & $\begin{array}{l}\text { Distance between movement vertical joints } \\
\text { between } 12 \text { and } 15 \mathrm{~m} \text {. }\end{array}$ & ㅁ & 1.000 \\
\hline & & $\begin{array}{l}\text { Distance between movement vertical joints } \\
\text { less than } 12 \mathrm{~m} \text {. }\end{array}$ & 口 & 1.033 \\
\hline
\end{tabular}

\begin{tabular}{|c|c|c|c|c|}
\hline \multirow{8}{*}{ 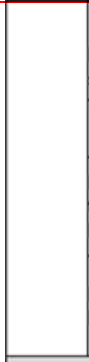 } & \multirow{3}{*}{$\begin{array}{l}\text { B.4 Transverse } \\
\text { stiffening of } \\
\text { facade planes. }\end{array}$} & $\begin{array}{l}\text { There is no transverse stiffening of facade } \\
\text { planes. }\end{array}$ & $\square$ & 0.967 \\
\hline & & $\begin{array}{l}\text { Transverse stiffening of those facade } \\
\text { planes whose length exceeds twice the } \\
\text { height. }\end{array}$ & 口 & 1.000 \\
\hline & & Transverse stiffening of all facade planes. & $\square$ & 1.033 \\
\hline & \multirow{2}{*}{$\begin{array}{l}\text { B.5. Conditions of } \\
\text { the outer clay } \\
\text { brick layer. }\end{array}$} & $\begin{array}{l}\text { Outer clay brick layer is supported by } \\
\text { horizontal structure. }\end{array}$ & $\square$ & 1.000 \\
\hline & & $\begin{array}{l}\text { Outer clay brick layer extends continuously } \\
\text { front of the structure. }\end{array}$ & $\square$ & 1.033 \\
\hline & \multirow{3}{*}{$\begin{array}{l}\text { B. } 6 \text { Colour clay } \\
\text { brick masonry. }\end{array}$} & dark & 口 & 0.967 \\
\hline & & medium & $\square$ & 1.000 \\
\hline & & clear & $\square$ & 1.033 \\
\hline & & Factor B: Design level. & & \\
\hline \multirow{5}{*}{ 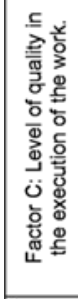 } & \multirow{3}{*}{$\begin{array}{l}\text { C. } 1 \text { Level of } \\
\text { control in the } \\
\text { execution. }\end{array}$} & $\begin{array}{l}\text { Execution category } \mathrm{C} \text { according to the } \\
\text { CTE-DB-SE-F. }\end{array}$ & $\square$ & 0.967 \\
\hline & & $\begin{array}{l}\text { Execution category } \mathrm{B} \text { according to the CTE- } \\
\text { DB-SE-F. }\end{array}$ & $\square$ & 1.000 \\
\hline & & $\begin{array}{l}\text { Execution category } \mathrm{A} \text { according to the CTE- } \\
\text { DB-SE-F. }\end{array}$ & $\square$ & 1.033 \\
\hline & \multirow{2}{*}{$\begin{array}{l}\text { C.2 Use of } \\
\text { retardant } \\
\text { additives in the } \\
\text { mortar of the } \\
\text { brickwork. }\end{array}$} & $\begin{array}{l}\text { Use of retardant additives in the mortar of } \\
\text { the brickwork. }\end{array}$ & $\square$ & 0.967 \\
\hline & & $\begin{array}{l}\text { Not use of retardant additives in the mortar } \\
\text { of the brickwork. }\end{array}$ & 口 & 1.000 \\
\hline \multicolumn{5}{|c|}{ Factor C: Level of quality in the execution of the work. } \\
\hline \multirow{2}{*}{ 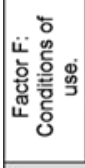 } & \multirow{2}{*}{$\begin{array}{l}\text { F.1 Exposure of } \\
\text { the facade to } \\
\text { vandalism. }\end{array}$} & $\begin{array}{l}\text { Commercial building located in area of } \\
\text { heavy pedestrian traffic and/or the } \\
\text { possibility of being vandalized. }\end{array}$ & ㅁ & 0.967 \\
\hline & & $\begin{array}{l}\text { No commercial building located in area of } \\
\text { heavy pedestrian traffic and without the } \\
\text { possibility of being vandalized. }\end{array}$ & 口 & 1.000 \\
\hline & & Factor F: Conditions of use. & & \\
\hline \multirow{7}{*}{ 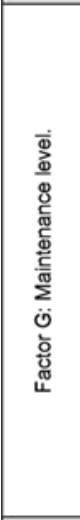 } & \multirow{3}{*}{$\begin{array}{l}\text { G.1 Accessibility } \\
\text { to the humid } \\
\text { facilities. }\end{array}$} & $\begin{array}{l}\text { There is no easy access for inspection and } \\
\text { repair of those humid facilities that, if they } \\
\text { have a leak, they could cause damage to } \\
\text { the facade. }\end{array}$ & 口 & 0.967 \\
\hline & & $\begin{array}{l}\text { There is a partial accessibility for inspection } \\
\text { and repair of those humid facilities that, if } \\
\text { they have a leak, they could cause damage } \\
\text { to the facade. }\end{array}$ & 口 & 1.000 \\
\hline & & $\begin{array}{l}\text { There is a total accessibility for inspection } \\
\text { and repair of those humid facilities that, if } \\
\text { they have a leak, they could cause damage } \\
\text { to the facade. }\end{array}$ & 口 & 1.033 \\
\hline & \multirow{2}{*}{$\begin{array}{l}\text { G.2 Incorporation } \\
\text { of mechanisms } \\
\text { for cleaning. }\end{array}$} & $\begin{array}{l}\text { There is no provision in project of } \\
\text { mechanisms for cleaning the facade. }\end{array}$ & $\square$ & 0.967 \\
\hline & & $\begin{array}{l}\text { There is provision in project of mechanisms } \\
\text { for cleaning the facade. }\end{array}$ & 口 & 1.000 \\
\hline & \multirow{2}{*}{$\begin{array}{l}\text { G.3 Level of } \\
\text { detail of the } \\
\text { maintenance } \\
\text { plan. }\end{array}$} & $\begin{array}{l}\text { Maintenance plan only provides generiq } \\
\text { operations. }\end{array}$ & $\square$ & 1.000 \\
\hline & & $\begin{array}{l}\text { Maintenance plan provides specific } \\
\text { operations for the building construction } \\
\text { systems, elements and materials. }\end{array}$ & 口 & 1.033 \\
\hline & & Factor G: Maintenance level. & & \\
\hline \multicolumn{3}{|c|}{$\begin{array}{l}\text { ESTIMATED SERVICE LIFE= Factor } \mathrm{E} \times \text { Factor } \mathrm{A} \times \text { Factor } \mathrm{B} \times \text { Factor } \\
\mathrm{C} \times \text { Factor } \mathrm{F} \times \mathrm{Factor} \mathrm{G} \times \text { Reference service life }\end{array}$} & $\cdots$ & \\
\hline \multicolumn{3}{|c|}{ MINIMUM ESTIMATED SERVICE LIFE } & 40 & \\
\hline \multicolumn{3}{|c|}{ MAXIMUM ESTIMATED SERVICE LIFE } & 150 & \\
\hline
\end{tabular}

